Article

\title{
The Current Dilemma and Future Path of China's Electric Vehicles
}

\author{
Xingping Zhang *, Rao Rao, Jian Xie and Yanni Liang \\ School of Economics and Management, North China Electric Power University, Box 80, Hui Long \\ Guan, Chang Ping District, Beijing 102206, China \\ * Author to whom correspondence should be addressed; E-Mail: zxp@ncepu.edu.cn; \\ Tel.:+86-106-177-3096; Fax: +86-108-079-6904.
}

Received: 14 January 2014; in revised form: 5 March 2014 / Accepted: 7 March 2014 /

Published: 20 March 2014

\begin{abstract}
China had set an ambitious development target of electric vehicles (EVs) to mitigate the environmental pollution. However, the actual situation of EVs far lagged behind the goals. This paper analyzes the elements impeding EVs' development, which are identified into four contributors, including deficient EV subsidy policies, embarrassed EV market, local protectionism, and unmatched charging infrastructure. Based on the actual situation of China, this paper discusses corresponding policy suggestions and explores the alternative roadmap of EVs. In the initial development stage of EVs, it is important to select the appropriate charging mode for EVs according to different characteristics across users. Moreover, the development of hybrid electric vehicle (HEV) may open the EV market faster than battery electric vehicle (BEV). In addition, the low-speed EVs may be a good choice for the rural market and should be well developed. With the promotion of EVs, China central and local governments should make rational policies to promote EVs' development, which is the crucial force to drive the uptake of EVs.
\end{abstract}

Keywords: electric vehicle; new energy vehicle; subsidy policy; development path of electric vehicles 


\section{Introduction}

\subsection{Does China Really Need to Develop Electric Vehicles?}

The traditional auto industry, as one of China's powerhouses to propel economic growth [1], has gained people's worries in terms of energy conservation and environment protection. The rapid development of fossil-fueled vehicles has increased the dependence on oil. Moreover, it is recently considered a main driver to aggravate cities' haze situation. Since 1993, China has become a net importer of crude oil with the dependency of six percent. China's oil consumption has risen steadily since the early 1990s [2] and the oil consumed by the transportation sector began to significantly rise. As seen in Figure 1, the oil consumed by transportation sector accounted for about $32.9 \%$ of domestic total oil consumption in 2005, and this ratio climbed up to $35.3 \%$ in 2011 Moreover, about $68 \%$ of the crude oil used in China was imported from other countries in 2010 [3] and things will be worsen in 2030 in that the International Energy Agency (IEA) has forecasted, China oil demand will reach 808 million tons, road transport will account for $43 \%$ and China's dependency on imported oil will rise to $80 \%$ [4]. This high import ratio will greatly impact the energy security and economic development of China.

Figure 1. Oil consumption and imports in China.

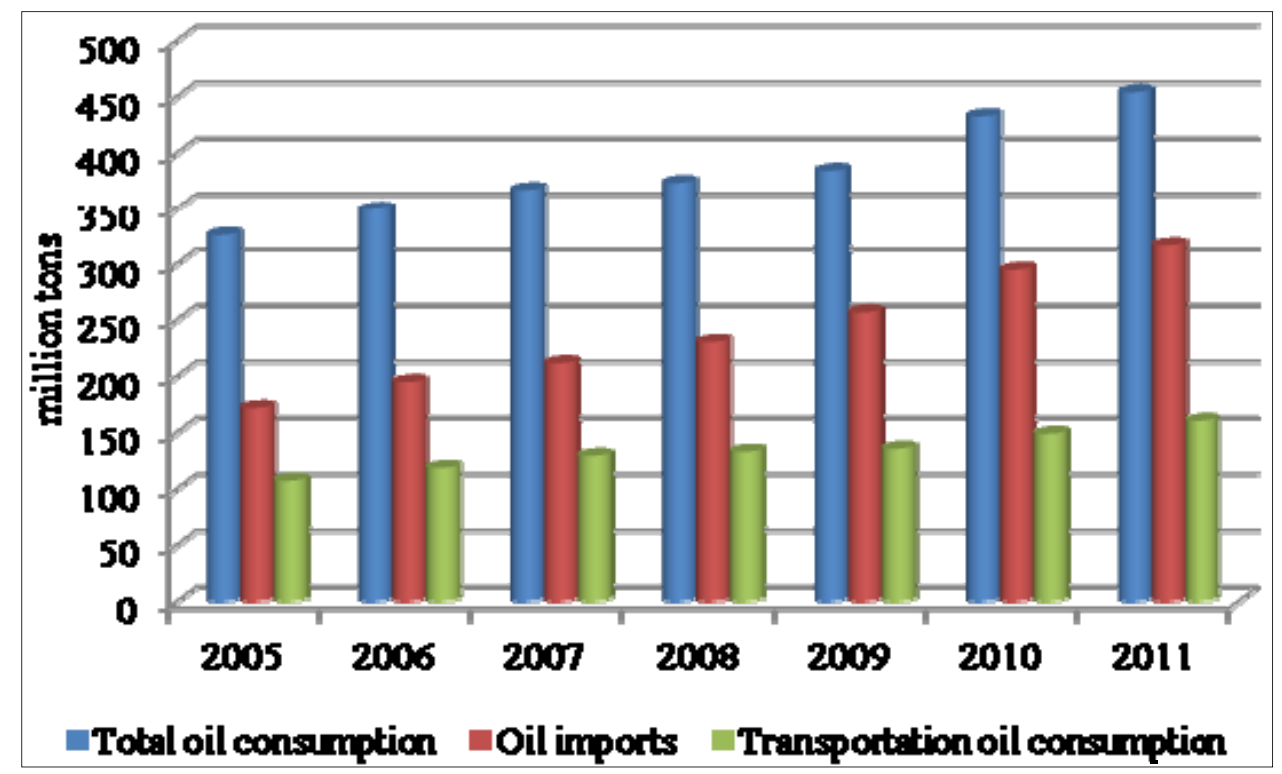

Source: National Bureau of Statistics of China [5].

As the world's most populous country, China's urbanization process is accelerating and a growing number of people have been pouring into cities. It is worth noting that the urbanization makes population overly collected in some big cities, such as Beijing, Shanghai, and Guangzhou. From Table 1, the number of cities with $0.2-0.5$ million people was decreasing, while that of cities with over one million people were, both, rising during 2006 to 2011, which means increasing people are flowing into megacities. Moreover, the population in urban area has increased by $35.9 \%$ in last ten years (Figure 2). Consequently, the rise of urban population must drive car sales up [6]. From Figure 3, the quantity of total private vehicles reached 73.3 million in 2011, about 10 times as large as that in 2001. Furthermore, 
it will increasingly rise with the rapid economic growth of China, and the corresponding problem of the pollution of megacities will be more serious.

Table 1. The number of cities under different population.

\begin{tabular}{lcccccc}
\hline & 2006 & 2007 & 2008 & 2009 & 2010 & 2011 \\
\hline over 4 million & 13 & 13 & 13 & 14 & 14 & 14 \\
$2-4$ million & 24 & 26 & 28 & 28 & 30 & 31 \\
$1-2$ million & 80 & 79 & 81 & 82 & 81 & 82 \\
$0.5-1$ million & 106 & 111 & 110 & 110 & 109 & 108 \\
$0.2-0.5$ million & 59 & 55 & 51 & 51 & 49 & 49 \\
under 0.2 million & 4 & 3 & 4 & 2 & 4 & 4 \\
Total & 286 & 287 & 287 & 287 & 287 & 288 \\
\hline
\end{tabular}

Source: National Bureau of Statistics of China[7].

Figure 2. Urban and rural population change in China.

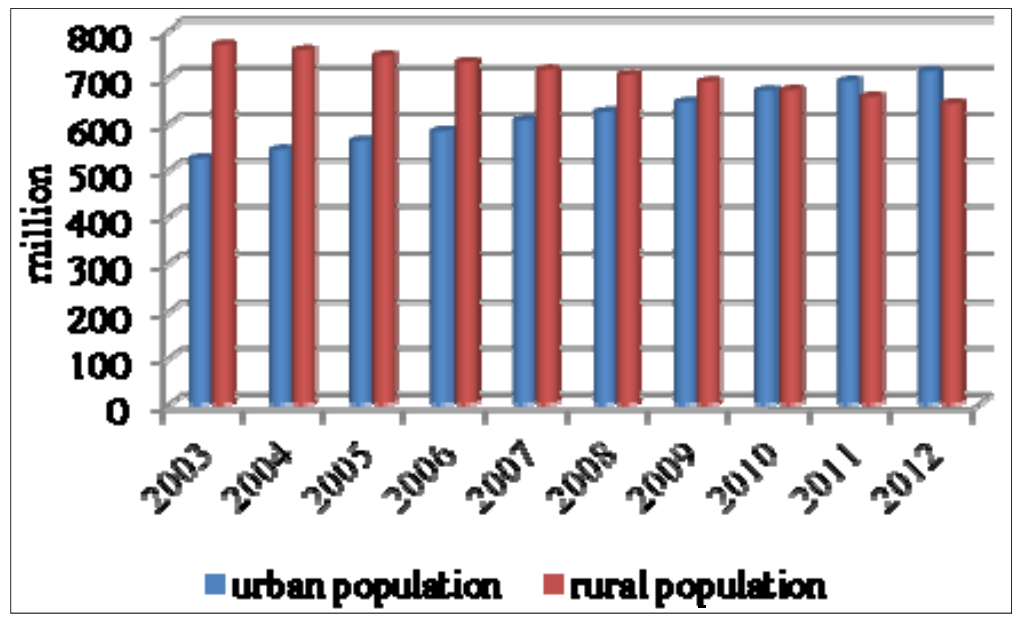

Source: National Bureau of Statistics of China [8].

Figure 3. The number of private vehicles in certain cites.

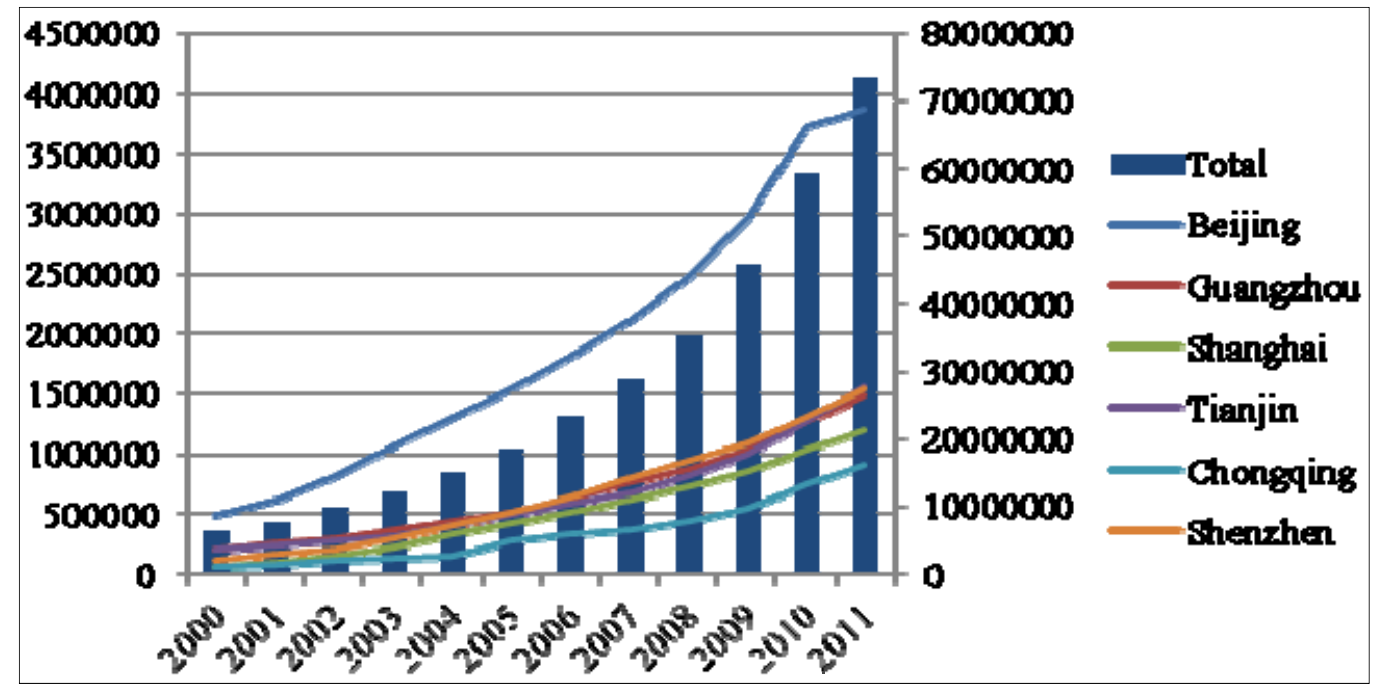

Source: China Statistical Yearbook 2011 [9]. 
Motor vehicles are also a major contributor to the air pollutants and greenhouse gas emissions [10]. Recently, China's increasingly serious haze problem raises concerns. Heavy polluting industries, huge coal consumption, and a large vehicle population are the three main drivers to the haze situation [11]. In Beijing, for example, the local government had removed heavy industry factories and power plants from the urban areas before the 2008 Olympic Games. However, Beijing still suffers from haze plight nowadays and it has experienced 124 haze days in 2012 (China Meteorological Administration).

Therefore, EVs are the most possible alternative to mitigate the environmental pollution of megacities. China's government has developed new energy vehicles (NEVs) as a national strategy and vigorously promoted application of automobile energy saving technology like developed countries. For the new energy automotive industry, "Automobile Industry Restructuring and Revitalization Plan (2009)" submitted that NEV production should reach 500,000 by 2012, and the "Energy-saving and New Energy Automotive Industry Development Plan (2012-2020)" further identified the world will usher important strategic opportunities of restructuring and upgrading for automotive industry over the next 10 years.

\subsection{Unfavorable Development of China's EV Market}

China's automobile industry foundation is not strong and there is a large gap between China and Europe, Japan, and other countries in independent research and development (R\&D). Moreover, investment in the field of EVs was carried out relatively late. During the phases of "Eighth Five-Year Plan" (1991-1995) and the "Ninth Five-Year Plan" (1990-2000), although China's government had funded the R\&D of EVs, the substantial investment was virtually input in the "Tenth Five-Year" (2001-2005) stage [12].

In March 2009, State Council issued "Automobile Industry Restructuring and Revitalization Plan" and put forward to form 500,000 capacities of battery electric vehicles (BEVs), plug-in hybrid electric vehicles (PHEVs), ordinary hybrid vehicles, and other NEVs, over the next three years. However, according to the data from Automobile Industry Development Institute of China (Figure 4), the average yield of the first nine months is 2482. Considering technical updates and corporate development, it can be inferred that the maximum total output of the planned three years (2010-2012) was around 100,000 cars, which lagged far behind the goal of 500,000 cars. According to the Ministry of Industry and Information Technology (MIIT), the total sales of 25 pilot cities had been only 10,000 NEVs up to July 2011 , of which only $10 \%$ were purchased by families, and most were purchased as the official or business car for enterprises and governments. According to the China Association of Automobile Manufacturers, domestic sales of BEVs were only 5579 in 2011 and 3444 in the first half of 2012. PHEVs were even less, only 81 in the first half of 2012.

In 2009, China's government launched “Ten Cities with Thousands Vehicles" program, which aimed at developing 10 cities each year and pushing $1000 \mathrm{NEVs}$ in each city over the next three years via financial subsidies. Initially, many cities were inspired and ambitiously established a four-year plan to grow ten to thirty thousand NEVs. However, the sum of NEVs in 25 pilot cities was around 10,000 annually, there is still a large gap between the reality and the expected goal. Facing that the development goals repeatedly failed to achieve, government, power companies, and automobile manufacturers have to restructure the development of EVs. Moreover, they should formulate corresponding policy guidance 
and related technical standards for the EV market. At this critical juncture, the Chinese EV industry is facing new challenges.

In this paper, we discuss the current situation of China's EVs in Section 2. Around the question "how to uptake the EV market in China and which path is more reasonable for China to promote EVs?" We put forward the corresponding countermeasures and suggestions in Section 3. Section 4 concludes this paper.

Figure 4. China's new energy vehicles monthly production in 2013.

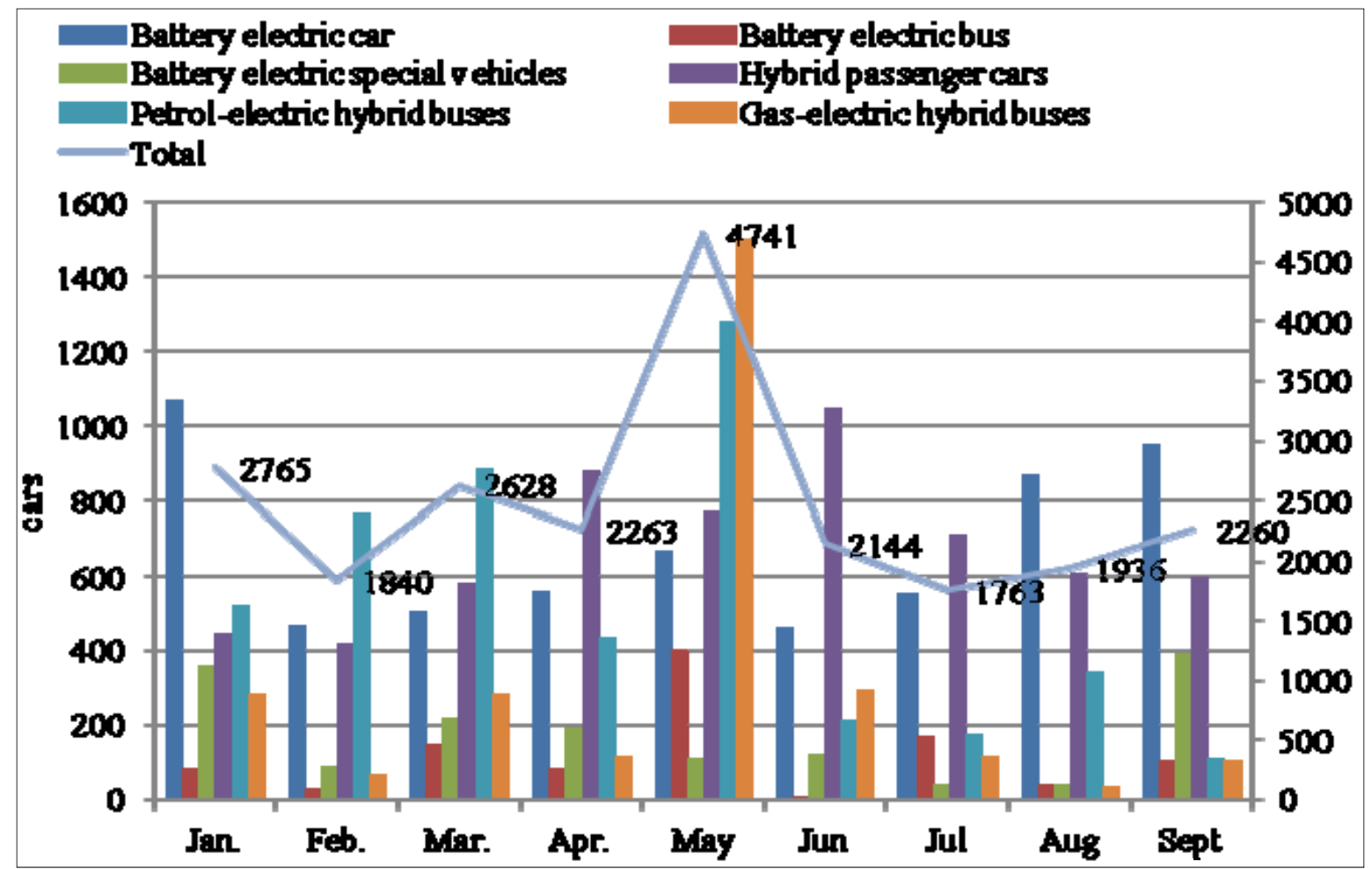

Source: Automobile Industry Development Institute of China [13].

\section{Status Quo}

\subsection{EV Industry Situation}

China put the development of EVs into the National Key Scientific and Technological Research Projects (863 Plan) in 1992 [14]. Then, China's Ministry of Science and Technology (MST) set up a "Three Verticals and Three Horizontals" special program in 2001. "Three Verticals" refers to HEV, BEV, and internal combustion engine vehicle (ICEV), while "Three Horizontals" indicates the power train control system, motor and its control system, and the battery and its management system. At present, China has formed a stable R\&D team, composed by more than 200 companies, universities, and research institutes [15]. Companies, such as First Automobile Works (FAW), Dongfeng Motor Corporation, SAIC Motor, Changan Automobile, Chery, Geely, BYD company, and others, are actively involved in the major R\&D projects of EVs, independently innovate EV technology, and create some market-oriented EV brands.

China government strives to make the volume of NEVs account for $10 \%$ of the automotive market by 2012. Beginning in 2009, China successively launched EV pilots in many cities to promote HEVs, BEVs, and ICEVs in public transportation, rental, service, sanitation, postal, and other public services, 
as well as the private purchase. However, battery technology barriers, high cost, inadequate infrastructure, short mileage, and safety problems still block the EVs promotion. From the China Association of Automobile Manufacturers and some pilot cities' statistics departments, we collected the data of electric buses and taxis in ten cities, which owned the top ten largest EV volumes in 2012. From Figure 5, the sum of EVs as public transportation in 2012 was about 8000. Although there was no domestic statistics on private EVs, it is not difficult to deduce that the target of $10 \%$ market share of the total automobiles was not achieved.

Figure 5. The number of public new energy vehicles in top ten cities.

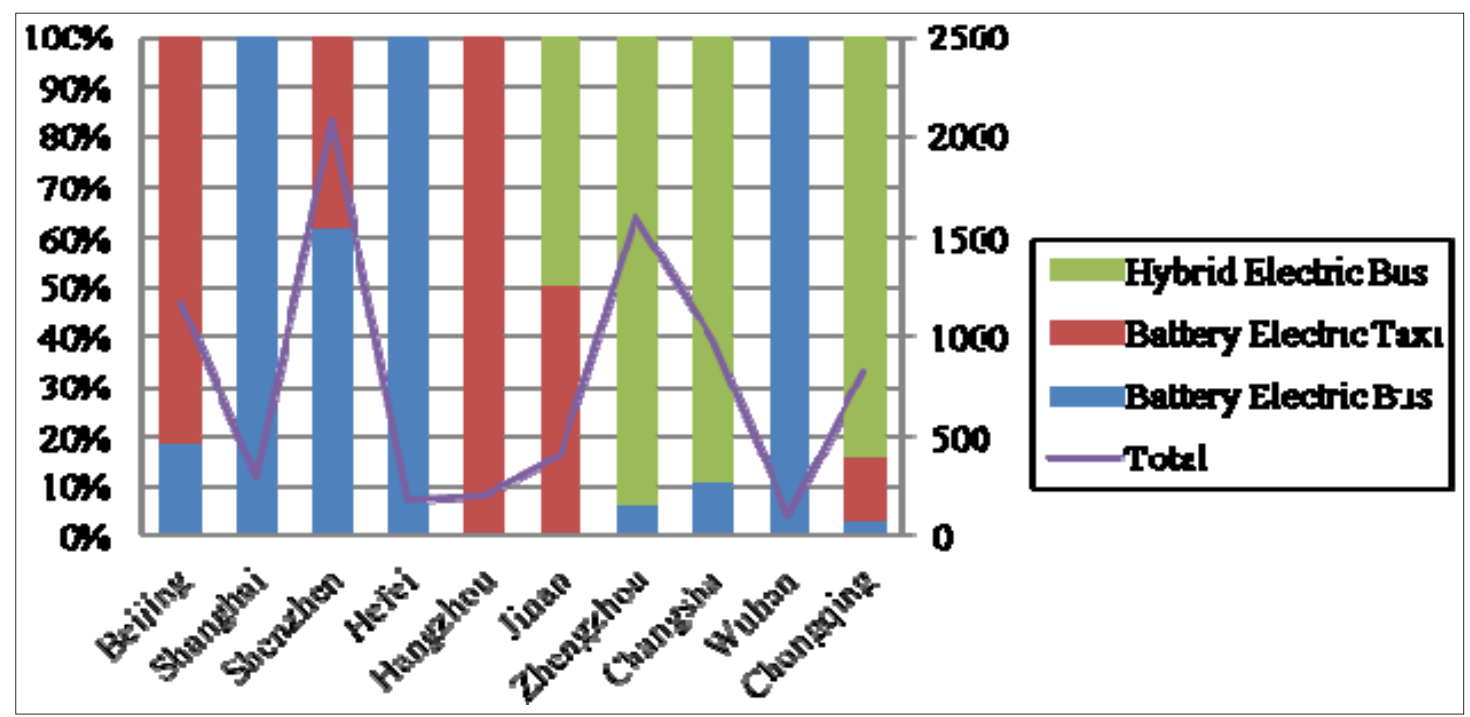

\subsection{Policy Environment for EVS}

\subsubsection{Pilot Policy}

Ministry of Science and Technology (MCT), Ministry of Finance (MF), National Development and Reform Commission (NDRC), and MIIT, jointly, launched the "Ten Cities with Thousands Vehicles" program in January 2009. Meanwhile, some local governments also formulated pilot development plans. The relevant pilot policies are arranged in Table 2. Thus far, most provinces and cities have realized electric buses on the road and formulated further public EV promotion plan.

\subsubsection{Infrastructure Promotion Policy}

Along with the development of the global EV industry, governments continue to strengthen the policy support of infrastructure construction. For instance, the U.S. government currently supports two charging infrastructure projects of "Charge Point" and "EV Project" and provides a refund policy for the installation of charging facilities in its economic stimulus bill. The American tax discount rate was 50\% in 2010, and 30\% in 2011, and the maximum subsidy of private purchase is $\$ 1000$ and that of enterprises amounts to $\$ 30,000$. The British government has launched charging station grants totaling $£ 30$ million, and the London government plans to build 25,000 charging points by 2015 . The Japanese government currently provides subsidies, mainly for public fast charging facilities, and its METI treats the total cost of fast charging equipment construction (including equipment and installation costs) as subsidies 
reference point, based on which the actual amount of subsidies could reach 50\% [16,17]. Meanwhile, electric companies have played an important role in infrastructure construction. Four power companies Rheinisch-Westfälisches Elektrizitätswerk (RWE), E.ON Group, Vattenfall, and Energie Baden-Württemberg (EnBW) involved in five out of eight regional demonstration projects conducted by the German government. In Italy, the Enel electric power company has occupied almost all the market of charging infrastructure. The Endesa power company has occupied the major market of charging infrastructure in Spain. In addition to the French government's power company, Citroen and Renault car companies have jointly signed an agreement to form an EV battery company [16].

Table 2. Pilot Promotion Policies.

\begin{tabular}{l|l|l|l}
\hline Time & Policy & Pilot cities & Content \\
\hline January & $\begin{array}{l}\text { "Notice on launching pilot } \\
\text { demonstration projects of } \\
\text { energy-saving and new } \\
\text { energy vehicle" [18] }\end{array}$ & $\begin{array}{l}\text { Beijing, Shanghai, Chongqing, } \\
\text { Changchun, Dalian, Hangzhou, } \\
\text { Jinan, Wuhan, Shenzhen, } \\
\text { Hefei, Changsha, Kunming, } \\
\text { and Nanchang }\end{array}$ & $\begin{array}{l}\text { Launch pilot demonstration } \\
\text { projects of energy-saving } \\
\text { and new energy vehicle. }\end{array}$ \\
\hline May 2010 & $\begin{array}{l}\text { "Notice on expanding the } \\
\text { demonstration } \\
\text { energy-saving and new } \\
\text { energy vehicle in public } \\
\text { services" [19] }\end{array}$ & $\begin{array}{l}\text { Tianjin, Haikou, Zhengzhou, } \\
\text { Xiamen, Suzhou, Tangshan, } \\
\text { and Guangzhou }\end{array}$ & $\begin{array}{l}\text { Launch pilot demonstration } \\
\text { projects of energy-saving } \\
\text { and new energy vehicle in } \\
\text { the newly added pilot area }\end{array}$ \\
\hline May 2010 & $\begin{array}{l}\text { "Notice on launching pilot } \\
\text { for purchase of private new } \\
\text { energy vehicle" [20] }\end{array}$ & $\begin{array}{l}\text { Shanghai, Changchun, } \\
\text { Shenzhen, Hangzhou, and } \\
\text { Hefei }\end{array}$ & $\begin{array}{l}\text { Prepare the implementation } \\
\text { plan of subsidy policy for } \\
\text { purchasing private NEV in } \\
\text { the pilot cities }\end{array}$ \\
\hline March & $\begin{array}{l}\text { "Guidance on promoting } \\
\text { application of new } \\
\text { energy vehicles in Jiangsu } \\
\text { province" [21] }\end{array}$ & $\begin{array}{l}\text { 2012-2014, focus in Nanjing, } \\
\text { Suzhou, Nantong pilot; } \\
\text { 2013-2015, select conditional } \\
\text { regions to continue } \\
\text { popularization and application } \\
\text { of NEVs in Wuxi, Changzhou, } \\
\text { Yancheng, Yangzhou, } \\
\text { Zhenjiang, and other places. }\end{array}$ & $\begin{array}{l}\text { Each pilot city should } \\
\text { respectively promote and } \\
\text { use more than 1,000 NEVs } \\
\text { in the pilot phase, among } \\
\text { which BEVs should make } \\
\text { up to over 50\%. }\end{array}$ \\
\hline
\end{tabular}

With the advancement of EV demonstration projects, the government's policy supports for electric charging infrastructure are continuously increasing. The State Grid, Southern Power Grid, and Sinopec enterprises actively participated in the charging infrastructure. State Grid and Southern Power Grid Company tend to provide battery replacement service. While the Sinopec group has proposed three promotion models. First is an operational development model of oil-driven power first and then petrol-electric combination. Second is a power supply model of direct-current fast charging-primarily, slow charging and small battery replacement aided. Third is a station construction path of building dual-use charging stations, based on the gas station network. Relevant policies about EV infrastructure construction in China are arranged in Table 3. 
Table 3. Infrastructure Promotion Policies.

\begin{tabular}{|c|c|c|c|}
\hline Time & Policy & Specific content & Time scope \\
\hline $\begin{array}{l}\text { December } \\
2007\end{array}$ & $\begin{array}{l}\text { "Catalogue for the } \\
\text { guidance of industrial } \\
\text { structure adjustment" }[22]\end{array}$ & $\begin{array}{l}\text { First proposed to encourage the construction of } \\
\text { NEV charging station project. }\end{array}$ & $\begin{array}{l}\text { Since the date of } \\
\text { execution }\end{array}$ \\
\hline $\begin{array}{l}\text { November } \\
2011\end{array}$ & $\begin{array}{l}\text { "Notice on further } \\
\text { improvement of pilot } \\
\text { demonstration projects of } \\
\text { energy-saving and new } \\
\text { energy vehicle" [23] }\end{array}$ & $\begin{array}{l}\text { Build charging piles for individual NEV users in } \\
\text { their residential or workplace's parking space, } \\
\text { and the ratio of charging piles to NEVs shall not } \\
\text { be less than } 1: 1 \text {; Set appropriate numbers of car } \\
\text { parking and charging piles in government } \\
\text { agencies, shopping malls, hospitals, or other } \\
\text { public areas. }\end{array}$ & $\begin{array}{l}\text { Since the date of } \\
\text { execution }\end{array}$ \\
\hline $\begin{array}{l}\text { December } \\
2011\end{array}$ & $\begin{array}{l}\text { "No. } 21 \text { national standard } \\
\text { announcement of the } \\
\text { People's Republic of } \\
\text { China in 2011" [24] }\end{array}$ & $\begin{array}{l}\text { Set four national standards which are "Electric } \\
\text { vehicle's conducting and charging interface part } \\
\text { 1: general requirements"; "Electric vehicle's } \\
\text { conducting and charging interface part 2: AC } \\
\text { charging interface"; "Electric vehicle's } \\
\text { conducting and charging interface part 3: DC } \\
\text { charging interface"; "The communication } \\
\text { protocol between the electric vehicle's } \\
\text { non-vehicle conductive charger and battery } \\
\text { management system". }\end{array}$ & $\begin{array}{l}\text { From } 1 \text { March 2012, } \\
\text { up to now }\end{array}$ \\
\hline $\begin{array}{l}\text { March } \\
2012\end{array}$ & $\begin{array}{l}\text { "The Twelfth-Five Year } \\
\text { special planning of the } \\
\text { technology development } \\
\text { of electric vehicles" [25] }\end{array}$ & $\begin{array}{l}\text { Build a network of power supply system which } \\
\text { is composed of around } 400 \text { thousands charging } \\
\text { piles and } 2000 \text { batteries swap stations in more } \\
\text { than } 20 \text { cities and areas. }\end{array}$ & Until 2015 \\
\hline
\end{tabular}

\subsubsection{Financial Subsidies}

In 2009, the MF and other departments issued the "Financial Subsidies Interim Measures for Energy-saving and New Energy Vehicles' Demonstration and Extension", which decided to give an one-time quota subsidies to public organizations who purchase energy-saving and NEVs in pilot cities. Meanwhile, domestic automobile enterprises have strengthened the development and production of NEVs. A total of 292 vehicle models had boarded "Energy-Saving and New Energy Vehicle Demonstration and Application Recommended Vehicle Model Directory", issued by NDRC, by August 2011, and the number of vehicle models climbed to 966 by January 2014. The vehicles included in the "Directory" could enjoy the state's fiscal subsidy [26]. It means "Directory" gives a vehicle an "identity" to be on the road. Since 1 June 2010, the government has successively developed private EV subsidy pilots in Shanghai, Shenzhen, Hangzhou, Hefei, Changchun, and Beijing, and formulated that the highest subsidy for private PHEV is 50,000 Yuan and 60,000 Yuan for BEV. Pilot cities have been encouraged to add a certain local subsidies based on the central government's subsidies. What worth noting is that subsidy scope is limited to vehicle models in the Directory. Relevant policies about price subsidies in China are shown in Table 4. 
Table 4. Price Subsidies Policies.

\begin{tabular}{|c|c|c|c|c|c|c|}
\hline Time & Policy name & Targets of subsidies & $\begin{array}{c}\text { The amount of } \\
\text { subsidies }\end{array}$ & Subsidy city & Subsidy method & $\begin{array}{l}\text { Subsidy } \\
\text { period }\end{array}$ \\
\hline $\begin{array}{c}\text { January } \\
2009\end{array}$ & $\begin{array}{l}\text { "Notice on launching } \\
\text { pilot demonstration } \\
\text { projects of } \\
\text { energy-saving and new } \\
\text { energy vehicle" [18] }\end{array}$ & $\begin{array}{l}\text { Energy-saving and new } \\
\text { energy vehicles and } \\
\text { related facilities }\end{array}$ & & & & \\
\hline $\begin{array}{l}\text { January } \\
2009\end{array}$ & $\begin{array}{l}\text { "Financial subsidy } \\
\text { interim measures for } \\
\text { energy-saving and new } \\
\text { energy vehicles' } \\
\text { demonstration and } \\
\text { extension in pilot } \\
\text { cities" [27] }\end{array}$ & $\begin{array}{l}\text { HEVs, BEVs, ICEVs in } \\
\text { buses, taxis, official } \\
\text { business, sanitation, postal, } \\
\text { and other public services, } \\
\text { also those included } \\
\text { "Energy-saving and new } \\
\text { energy vehicle } \\
\text { demonstration and } \\
\text { application recommended } \\
\text { vehicle model directory" }\end{array}$ & $\begin{array}{l}\text { Bus: RMB 420,000 } \\
\text { Yuan for HEVs, RMB } \\
500,000 \text { Yuan for } \\
\text { BEVs and RMB } \\
600,000 \text { Yuan for } \\
\text { ICEVs; } \\
\text { Passenger cars and } \\
\text { light commercial } \\
\text { vehicles: RMB 50,000 } \\
\text { Yuan for HEVs; RMB } \\
60,000 \text { Yuan for } \\
\text { BEVs; RMB 250,000 } \\
\text { for ICEVs. }\end{array}$ & $\begin{array}{l}\text { Beijing, } \\
\text { Shanghai, } \\
\text { Chongqing, } \\
\text { Changchun, } \\
\text { Dalian, } \\
\text { Hangzhou, } \\
\text { Jinan, Wuhan, } \\
\text { Shenzhen, } \\
\text { Hefei, } \\
\text { Changsha, } \\
\text { Kunming, } \\
\text { Nanchang }\end{array}$ & $\begin{array}{l}\text { One-time fixed } \\
\text { subsidies are paid } \\
\text { to vehicle buyers. } \\
\text { Vehicles for } \\
\text { personal use have } \\
\text { not yet been } \\
\text { included in the } \\
\text { policy. }\end{array}$ & $\begin{array}{l}\text { Since the } \\
\text { date of } \\
\text { executio } \\
\text { n }\end{array}$ \\
\hline $\begin{array}{l}\text { May } \\
2010\end{array}$ & $\begin{array}{l}\text { "Financial subsidy } \\
\text { interim measures for } \\
\text { private purchase of new } \\
\text { energy vehicle in pilot } \\
\text { cities" [28] }\end{array}$ & $\begin{array}{l}\text { Give a one-time subsidy to } \\
\text { private purchased, } \\
\text { registered and usable } \\
\text { PHEVs and BEVs in pilot } \\
\text { cities. }\end{array}$ & $\begin{array}{l}\text { Provide subsidies } \\
\text { according to RMB } \\
3000 \text { Yuan/kwh, the } \\
\text { maximum subsidy of } \\
\text { PHEV is RMB } 50,000 \\
\text { Yuan per vehicle, and } \\
\text { that of BEV is RMB } \\
60,000 \text { Yuan } \\
\text { per vehicle. }\end{array}$ & $\begin{array}{l}\text { Shanghai, } \\
\text { Changchun, } \\
\text { Shenzhen, } \\
\text { Hangzhou, } \\
\text { Hefei }\end{array}$ & $\begin{array}{l}\text { Subsidy funds are } \\
\text { allocated to auto } \\
\text { manufacturers. }\end{array}$ & $\begin{array}{l}2010- \\
2012\end{array}$ \\
\hline $\begin{array}{l}\text { October } \\
2012\end{array}$ & $\begin{array}{l}\text { "Management approach } \\
\text { on the private purchase } \\
\text { of BEVs in Beijing (tria } \\
\text { implementation)" [29] }\end{array}$ & $\begin{array}{l}\text { Give a one-time subsidy to } \\
\text { private purchased, } \\
\text { lregistered and usable } \\
\text { plug-in hybrid cars and } \\
\text { pure electric passenger } \\
\text { vehicles in Beijing. }\end{array}$ & $\begin{array}{l}\text { Provide subsidies } \\
\text { according to RMB } \\
3000 \text { Yuan/kwh, and } \\
\text { the maximum subsidy } \\
\text { is } 60,000 \text { Yuan } \\
\text { per vehicle. }\end{array}$ & Beijing & $\begin{array}{l}\text { State subsidies are } \\
\text { allocated to } \\
\text { production } \\
\text { enterprises; } \\
\text { Beijing subsidies } \\
\text { are allocated to the } \\
\text { purchase } \\
\text { departments and } \\
\text { individuals. }\end{array}$ & $\begin{array}{l}\text { Since the } \\
\text { date of } \\
\text { executio } \\
\text { n }\end{array}$ \\
\hline
\end{tabular}

\subsubsection{Tax Policy}

For EV promotion, countries that developed EVs early have introduced various tax incentives. The U.S. "Emergency Economic Stabilization Act of 2008" stipulated that those who bought more than 
$4 \mathrm{kWh}$ energy storage battery plug-in EVs could get $\$ 7500$ tax credit deals and it expanded the tax credit for EV infrastructure by increasing the 30\% tax credit on the basis of "Energy Policy Act of 2005" [30,31]. Michigan Economic Growth Authority has announced to provide \$543 million to Johnson and three other battery manufacturers as tax incentives. UK government provides free license tax and road maintenance fee for EV owners. Germany government gives excess subsidies, low-interest loans, and a $7 \%$ tax discount to individuals [17]. In Japan, the EV buyers can enjoy free, $75 \%$ or $50 \%$ reduction of the automobile acquisition tax and automobile weight tax according to different models and indicators [32]. Since 2006, China has introduced a variety of tax policies, reported in Table 5, to clear about the objects of tax cuts and tax deduction. At the current stage, coverage of tax policy mainly focuses on the vehicle purchase and enterprises on the EV industry chain, while battery replacement and supporting infrastructure are absent.

Table 5. Tax subsidy policies.

\begin{tabular}{l|l|l|l}
\hline Time & Policies & Objects & Specific content \\
\hline 2006 & $\begin{array}{l}\text { New consumption tax } \\
\text { policy [33] }\end{array}$ & $\begin{array}{l}\text { Car with energy saving } \\
\text { features }\end{array}$ & $\begin{array}{l}\text { First time to propose the } \\
\text { implementation of certain tax benefits } \\
\text { for NEVs }\end{array}$ \\
\hline $\begin{array}{l}\text { December } \\
2011\end{array}$ & $\begin{array}{l}\text { "Vehicle and vessel tax } \\
\text { implementation methods } \\
\text { in Henan province" [34] }\end{array}$ & $\begin{array}{l}\text { Energy-conservative } \\
\text { vehicles and vessels }\end{array}$ & $\begin{array}{l}\text { Derate vehicle and vessel tax of } \\
\text { certain models of vehicles }\end{array}$ \\
\hline $\begin{array}{l}\text { January } \\
2012\end{array}$ & $\begin{array}{l}\text { "Bulletin of directory of } \\
\text { BEVs and ICEVs } \\
\text { models which are not } \\
\text { free of travel taxes" [35] }\end{array}$ & $\begin{array}{l}42 \text { types of BEVs, and } \\
7 \text { types of ICEVs }\end{array}$ & $\begin{array}{l}\text { Derate vehicle and vessel tax of } \\
\text { certain models of vehicles }\end{array}$ \\
\hline $\begin{array}{l}\text { March } \\
2012\end{array}$ & $\begin{array}{l}\text { Notification from } \\
\text { combination of Ministry } \\
\text { of Finance, State } \\
\text { Administration of } \\
\text { Taxation and MIIT [36] }\end{array}$ & $\begin{array}{l}\text { Energy saving vehicles } \\
\text { and vessels and those } \\
\text { with new energy }\end{array}$ & $\begin{array}{l}\text { Halve the vehicle and vessel tax of } \\
\text { energy saving vehicles, while derate } \\
\text { all of new energy vehicles }\end{array}$ \\
\hline
\end{tabular}

\subsubsection{Research and Development Investment}

During the "Tenth Five-Year Plan" period (2001-2005), the national research program "Clean Car Key Technology Research Development and Demonstration Application" established a clean vehicle technology development and application system. The project has successfully developed 19 kinds of engines and vehicles, of which emissions met the national standard. It has also realized mass production ability and some products have been already on the market. During the "Eleventh Five-Year Plan" period (2006-2010), a major project named "Energy Conservation and New Energy Vehicles" (a part of "863" plan) was launched in 2006. Based on this project, China has basically mastered the core technology, demonstrated more than 5,000 EVs of various types, initially formed a production capacity of 150,000 EVs, and stipulated more than 160 kinds of EVs into new product announcements. During the "Twelfth Five-Year Plan" period (2011-2015), the main goals of "Modern Transportation Technology of EV Technology and System Integration" is to carry out the industrial technology research and development of HEV products, to develop series BEV and its energy supply systems, as well as EV 
technology and business operation mode. Moreover, it puts forward to developing high-end cutting-edge technology represented by ICEVs and building the next generation of PE power system technology platform. R\&D investments in each period are shown in Table 6.

Table 6. Research investment in each period.

\begin{tabular}{l|l|l|l}
\hline Time & Project Name & Deadline & Investment \\
\hline $\begin{array}{l}\text { September } \\
2001\end{array}$ & $\begin{array}{l}\text { "863" Special } \\
\text { plan_-"Development and } \\
\text { application of Key technologies } \\
\text { of clean energy vehicles" [37] }\end{array}$ & 2001-2005 & $\begin{array}{l}\text { National finance granted 880 million } \\
\text { Yuan, and local governments and } \\
\text { enterprises 1.4 billion Yuan }\end{array}$ \\
\hline $\begin{array}{l}\text { September } \\
2006\end{array}$ & $\begin{array}{l}\text { "86" plan—“Energy saving and } \\
\text { new energy vehicles" [38] }\end{array}$ & $2006-2010$ & $\begin{array}{l}\text { National finance granted 11.6 billion } \\
\text { Yuan, and local governments and } \\
\text { enterprises 11 billion Yuan }\end{array}$ \\
\hline $\begin{array}{l}\text { September } \\
2011\end{array}$ & $\begin{array}{l}\text { "863" plan_-Key technology } \\
\text { and system integration of EV in } \\
\text { modern transportation } \\
\text { technology area" [39] }\end{array}$ & $2011-2015$ & $\begin{array}{l}\text { National finance granted 738 million } \\
\text { Yuan, the local governments and the } \\
\text { enterprises funds have not yet been } \\
\text { published. }\end{array}$ \\
\hline
\end{tabular}

\subsection{Obstacles for EV Development}

\subsubsection{Unresolved Pollution Problems}

It seems rational that the development of EVs can reduce greenhouse gas emissions in the transportation areas and ease our dependence on oil resources [40]. However, it is important to understand how the availability of low carbon electricity from energy sources may influence the carbon-emission of EVs [41]. Electricity generation mix in China is dominated by coal-fired power, and $79 \%$ of electricity was generated from coal in 2009 [42], though the proportion dropped to $69.6 \%$ in 2013 [43], it still kept high. Thus, the promotion of EVs is essentially replacing low-carbon with high-carbon and substituting concentrated discharge with disperse emissions. Therefore, the charging mode is very important to mitigate the pollution. For example, it is the best way to be charged by clean energy or charge at low load times.

In addition, although there is no pollution emission in EV itself, its indirect pollution cannot be ignored. For example, lead in lead-acid batteries can cause pollution to the environment from mining, smelting to product sewage. As the mainstream of the EV battery products worldwide, lithium ion batteries do not have heavy metal pollution, such as lead, cadmium, and mercury, but own fluoride and organic pollution in the case of water-electrolyte and possess other potential risks. At present, the lithium ion battery has not been applied in China to a large-scale and there is no obvious recycling problem concerning waste lithium ion batteries. Therefore, the state has not yet introduced relevant regulations and standards of mandatory recycling, which needs our attention. 


\subsubsection{Grim EV Technology Problems}

\subsubsection{Constraints of Battery Technology}

Currently, EVs in the domestic market can drive theoretically $200-300 \mathrm{~km}$ on a single charge. To maintain the distance, they usually need an appropriate speed and a good battery control system, while the trip range of vast majority of EVs is only $50-150 \mathrm{~km}$ in general driving environment, a fatal weakness compared with traditional ICEVs.

In addition, an ordinary battery's charge and discharge time is only 300-400 times and that of good performance battery is about 700-900 [44,45]. Thus, battery life is up to about four years according to 200 times per annum, which lead to a larger cost compared to ICEVs.

In addition, different type of batteries has its own advantages and disadvantages in terms of performance. For example, lead-acid battery features low cost, abundant raw materials, and good recyclability, but short travel distances, poor acceleration power, and short service life. Nickel-cadmium battery has enough accelerated power and longer life expectancy, but high cost and poor recyclability, and its discharge performance in high-power situation is not as good as some other technologies. Sodium-sulfur battery's highlights are higher energy density and longer driving range, but it requires more demanding work environment and its active substance has strong corrosivity and explosibility. The most obvious drawback of Li-ion technology is the complexity of charging and safety [44].

Moreover, existing batteries used in EVs cannot balance a reasonable size and quality under the premise of sufficient energy storage [46]. For instance, outer volume of existing domestic EV battery is generally $550 \mathrm{~L}$, it's bound to squeeze the family car luggage space when using such a large volume of battery.

\subsubsection{High EV Prices}

The price of EV keeps high due to the complexity of battery technology, high cost and the application of new materials. The prices of EVs or HEVs sold in China are collected in the Appendix [47,48]. Meanwhile, annual disposable income per capital of urban residents and the average annual wage of urban workers from 2002 to 2011 are collected respectively in Figure 6 (National Bureau of Statistics [49]). By comparison, the average price of EVs in the Appendix is 605,266 Yuan, nearly 15 times of average wage of urban workers in 2011, and 30 times of disposable income per capital of urban residents in 2011. Moreover, though the prices of some vehicles are comparable to some types of traditional ICEVs, inconvenient charging infrastructure may increase people's concerns. In addition, limited mileage, imperfect after-sales service, and other factors actually lower EV price's competitiveness. As shown in Table 7 [48], though the prices of these EV models are lower than 100,000 Yuan, their performance cannot well meet the needs of users. 
Figure 6. Urban annual income per capital in China.

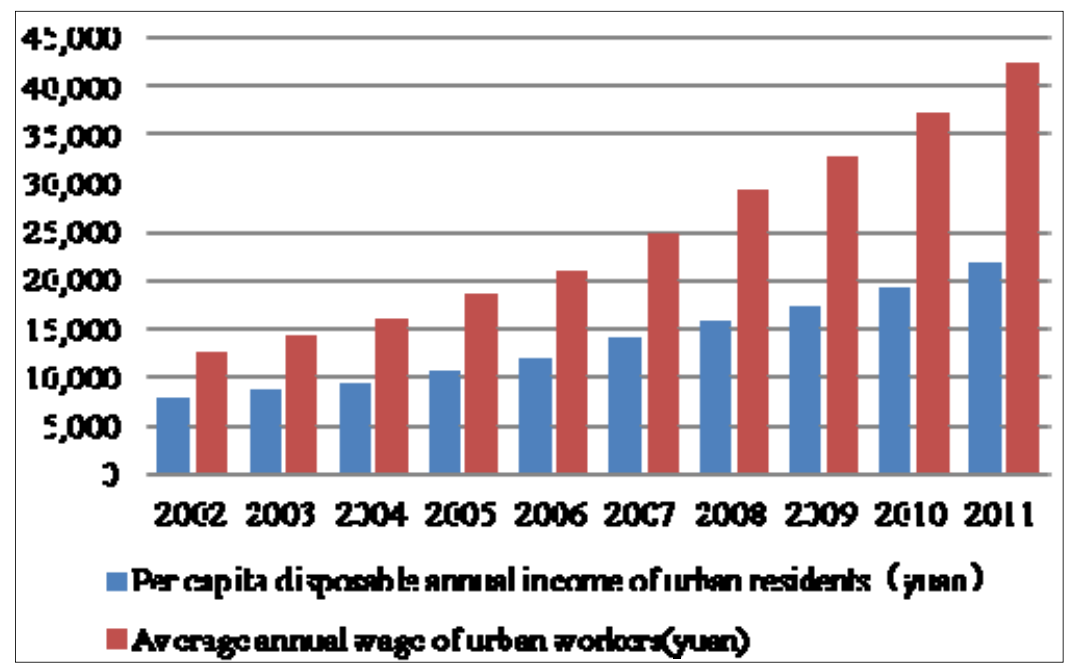

Table 7. Performance of some types of EVs.

\begin{tabular}{lccccc}
\hline \multicolumn{1}{c}{ Model } & $\begin{array}{c}\text { Current } \\
\text { price(Yuan) }\end{array}$ & $\begin{array}{c}\text { Mileage } \\
(\mathbf{k m})\end{array}$ & $\begin{array}{c}\text { Charging } \\
\text { Time(h) }\end{array}$ & $\begin{array}{c}\text { Maximum } \\
\text { speed(km/h) }\end{array}$ & $\begin{array}{c}\text { Consumption } \\
\text { per 100 km(kwh) }\end{array}$ \\
\hline Changan Benni & 100,000 & 105 & 8 & 120 & \\
Geely EK2 & 80,000 & 180 & 6 & 150 & 11.2 \\
JAC Tojoy & 98,800 & 150 & 8 & 95 & 13 \\
Chery QQ3 & 52,800 & 120 & 9 & 80 & 15 \\
Roewe E1 & 80,000 & 150 & 2.5 & 125 & \\
Citroen C-Zero & 45,000 & 150 & 5 & 130 & \\
\hline
\end{tabular}

\subsubsection{EV Market Embarrassment by Policy Constraints}

\subsubsection{No “Identity” EV: Low-Speed EV’s Development Dilemma}

There is no "Identity" for an EV if it is not entered in the national energy-saving and new energy automotive products directory. Correspondingly, it cannot enjoy the state's subsidies. Currently, though BEV is strongly supported by the China government, it still possesses sluggish market performance owing to its high price, limited mileage, and inconvenient operation. Eventually "hot policy" runs into "cold market". On the contrary, in recent years, small EV (or low-speed EV) has been developing extremely fiercely in some counties and towns, and it has achieved tens of thousands of sales in Shandong and Hefei provinces [50]. Compared with general EVs, the price of low-speed is much cheaper, nearly $1 / 5$ of the price of general EV. Though it owns slow traveling and short mileage, it is easy to operate and suitable for rural people's habits. Therefore, this kind of EV, which is energy-saving as well, is touted in the rural areas. However, though low-speed EVs are hot sales, they walk in the edge of national laws and policies because of identity embarrassment. Due to lack of related policies and technical norms, some low-speed EV manufacturers entered the market with an illegal status. Moreover, the absence of management systems leads to no qualification, poor quality, and low safety of low-speed EVs. Ultimately "hot market" suffers from "cold policy" [51]. 


\subsubsection{Local Protectionism}

At the present stage, China's subsidy policies are mainly distributed to pilot cities and applied to car purchase. On the one hand, it's widespread to sell one's own products in the production place, on the other hand, the local governments of pilot cities always open green lights for local EV manufacturers and internally digest EV subsidies. As a result, a local protective barrier is formed. Therefore, lack of fair and free competition environment will restrict the healthy development of EV market and further impede technological innovation and progress.

Local protectionism trend is mainly reflected in the license restrictions and selective subsidies. There are many restrictions for EV license in some cities. For instance, the famous EV BYD e6 Pioneer is currently only listed in Shenzhen and without any sales plan in other non-pilot cities because it does not enjoy any subsidies in these cities. Owing to local protectionism, new energy vehicles' market entry, and licensing are always monopolized by local automobile manufacturers. Meanwhile, some EVs which are not been quality-detected, of no standard and not belong to the directory are permitted to travel on the road in some cities due to the protection of local enterprises, which fundamentally prevents foreign excellent EVs into local market and forms protection of laggard products, as well as market monopoly [52].

\section{How to Establish a Stable EV Market in China?}

China has formulated a lot of policy supports for EV promotion, but the volume of the actual EV development is still far behind the plan. How to effectively uptake the EV market is an urgent issue we must pay attention to. This paper will discuss several key problems through factual proof and policy analysis.

\subsection{Battery EV or Hybrid EV}

Most domestic people have clearly recognized that the EV market still needs 10 or more years to achieve. The coexistence of multiple energies will last a long time and there is no any sign that traditional ICEVs will out of market. Therefore, the EV development should be a long-term strategy, not a short-term behavior.

From the perspective of energy conservation, studies demonstrated that HEVs have more benefits than both BEVs and ICEVs currently and in the near future (2030) in China [53,54].This is especially true for the Jing-Jin-Ji Region of China, where coal is an overwhelming power source. In those regions with a high share of coal power, $\mathrm{HEV}$ is a better choice than $\mathrm{BEV}$ to reduce $\mathrm{CO}_{2}$ emissions [42]. The theoretical $\mathrm{CO}_{2}$ breakeven point between BEVs and HEVs is $60 \%$ coal power, which means that BEVs would have $\mathrm{a}_{2}$ reduction advantage over $\mathrm{HEVs}$ if the coal power proportion is below $60 \%$. However, many projections for the coal power proportion in China are higher than $60 \%$ in 2030 [55]. Besides, it is estimated that by 2030, if fuel economy reaches Japan's present level and HEV attains $50 \%$ of the market share in China, China's transport could probably realize $42 \%$ energy saving in vehicle fuel consumption [56].

From the perspective of technology, the battery energy storage issue is still a fatal weakness. In terms of energy density, the ratio of EV to ICEV is about 1:100, that is to say, if an ICEV's fuel consumption is 10 liters per hundred kilometers, it can run $500 \mathrm{~km}$ with 50 liters (nearly $37 \mathrm{~kg}$ ) in the tank. However, an EV must install more than 3.5 tons of batteries to achieve the same distance in current Chinese 
technology. While for HEV, because it uses both internal combustion engine and electric motors as power sources to move itself, it could have a relatively higher energy storage capacity compared to BEV [57]. The relevant EV technologies are still in R\&D phase and difficult to put into market. Therefore as a transition, HEV is more realistic solution in this case [58].

From the perspective of supporting infrastructure, domestic charging infrastructure is still lacking, especially fast-charging stations. Meanwhile, the high construction costs and, yet, unified charging station interface standard are also restricting the rapid development of BEV market. In contrast, HEV owns a more convenient way for energy supply. Thanks to its characteristics of energy source, additional charging equipment is not indispensable. They could get charged through both gas station and charging station/pile. That is to say, they could be developed based on existing infrastructure.

\subsection{Public EV or Private EV}

Since 2009, when China promoted EVs, the market of private EVs has still been slacking. It's difficult for the private market to harbor the NEVs due to a series of reasons, like the extravagant price, the imperfect performance of the vehicles and inadequate infrastructure. In addition, criteria, such as charging time, costs/benefit, appeal/status, risk, and comfort, also influence the purchase of consumers $[47,59,60]$. According to the results of the survey supplied by the Ernst and Young global auto center, the main determinants which significantly influence Chinese consumers to buy a HEV or BEV are fuel-efficient, environmental effect, safety, and incentives of the government. Moreover, the survey also provides what makes the respondents hesitant when buying EVs, the answers are the following factors: battery range, the charging station distance, reliability, security, performance, price, battery maintenance, technical limitations, and the number of seats [61]. Because it is difficult to solve these problems in a short period of time, domestic experts believe that if we intend to make a large volume development of EVs, breakthrough will still be in the bus, taxi, sanitation vehicle, and other public transport.

Considering energy conservation and emissions reduction, orderly charging can significantly reduce the burden of power grid through achievement of collaborative scheduling of renewable energy (wind, solar, etc.). However, disordered charging of EVs will increase the negative effect on the grid. In general, the way of ordered charging will not only attain the settlement of low-carbon energy, but also address the current renewable energy consumptive problem in China. Due to the diversity of private charging mode, the large-scale development of private EVs will lead to predicament of disordered charging. Government and power enterprises should promote some policies about electricity price or restrictions, which can effectively guide the private users' behavior of charging. Compared to this, public transports, mainly refers to electric buses and taxis, have some strengths. They possess regular running time and route, it, therefore, could realize orderly charging.

In terms of infrastructure, firstly, private users' demand is difficult to predict, while public transport, which can be commanded by government policies or company has more certainties. Thus, it is beneficial to promote public transport for determining the scale of facilities on battery replacement or direct charging. Secondly, parking remains a problem in China. For example, half of the automobiles have no parking places in Beijing at present, so they have to park on the street or indiscriminately park in some areas, where charging piles cannot be established. Compared with charging station, charging pile is a 
kind of convenient charging equipment, it does not need additional cost of land expropriation and both of its construction cost and artificial cost are low. However, an EV generally needs to be charged for 6-8 h via charging piles, much slower than charging stations. In addition, to gain the approval from the planning department for parking building construction is extremely difficult. Moreover, the inconvenience caused by the deficiency of supporting facilities will reduce consumers' enthusiasm on purchasing EVs and the lower expectations for the EV market share in turn cuts down the investment returns of charging infrastructure construction. All of the above would be detrimental for the development of private EVs. However, advancing public EVs will not be easily troubled by these. It is a prerequisite to build fixed parking space for public transport, which could realize the centralized charging. In addition, because of fixed driving route, it could generally guarantee the normal driving without additional charging or at least reducing the charging times. Ultimately, the promising path is to advance public EVs and infrastructure construction as the breakthroughs, through which to stimulate the development of the entire EV market.

From the perspective of government subsidy, firstly, fiscal subsidies have been concentrated more on public transportation from Table 4 and cities with private EV subsidy are only Shanghai, Hangzhou, Hefei, Changchun, Shenzhen, and Beijing. Secondly, subsidy for corporate is the main manner of the subsidy policy for private EVs in pilot cities. This way seems to have more advantages because it can reduce administrative procedure in the process of tax subsidies, while certain drawbacks still exist, such as the difficulty to determine whether the consumers enjoy the full-specified amount of government subsidies, as well as the lack of relevant supervision departments who could supervise on the employment of subsidies. All these disadvantages will curb consumers' purchase intention. Reversely, this kind of situation will not appear in public transportation companies.

It is worth nothing that China has numerous official automobiles. According to statistics, there had been 5,221,755 official cars in China by 30 November 2007, equivalent to nearly $20 \%$ of overall private automobiles in 2007 [62]. Although the number of official vehicles has decreased through the reform in recent years, their total amount is still large. Generally, most official vehicles run within the scope of city and may suit for running by EVs. Therefore, the special case of China's official vehicles provides a possible alternative to EV development as well. On this occasion, China's central and local governments should promote the event.

To sum up, it should still strongly concentrate on the public transportation first in the future for the uptake of Chinese EV market, so as to drive the construction of supporting facilities and influence people's concept in the use of EVs. Finally, the whole EV market will be well established.

\subsection{Direct Charging or Battery Replacement}

The debate on whether direct charging or battery replacement has never been stopped since 2008 . Behind the debate, an invisible hand works, that is the interests of different stakeholders, which are mainly composed by power grid companies and automobile companies, then government makes the final decision [63]. During the conflict, the power grid companies support the mode of changing batteries, so as to monopolize the energy supply of BEVs by controlling batteries and grabbing the main links of the industry. However, the automobile companies give priority to the charging mode, because they are worrying about the loss of huge state subsidies, as well as poor sales of produced plug-in EVs. 
From the point of power grid companies, the State Grid and Southern Power Grid companies agree with the operation mode which refers to "mainly in battery replacement and supplemented by charging". This path mainly depends on the influence for the grid in the following two ways:

(1) In terms of power load, several factors work on it, such as the charging behavior of the EV users, the driving characteristics of the EVs, the distribution of charging facilities and charging power, among which the charging behavior of EV users has the most significant impact. Since China is still at the promotion stage and the ownership of EVs is small, EVs have small impact on the load at present. However, the load issue will be taken seriously in a short period based on the development momentum of EV. Serious haze problems these years have pushed the central government and some local governments to formulate several policies to speed up the development of EVs. For example, In Beijing, the local government put forward that the EV capacity will achieve 100,000 by 2015 . For the whole country, the central government is vigorously promoting the EV infrastructure construction to achieve the goal of building 400,000 charging piles and 2000 charging or battery displacement stations in more than 20 cities by 2015 . In addition, China has not established corresponding scheduling mechanism and it seems likely that the mechanism will not be achieved in a short time. Under this circumstance, the battery replacement mode could realize centralized control, which will reduce or avoid the adverse impact on the power load if conduct is orderly. While direct charging way, due to its scattered distribution and diversity, always leads to the growth of maximum load, as well as the peak and valley difference.

(2) In terms of distribution grid, there is no need to modify the existing distribution grid if battery stations were reasonably selected, while it is not the case for charging stations. It would not need to transform $10 \mathrm{kV}$ distribution grids under the AC slow charging mode for vast majority of communities and commercial office buildings, only if EVs are accounting for over $20 \%$ of total automobiles. Moreover, a larger number of EVs, a higher charging rate and more random charging behaviors will intensify the reform of the distribution grids under the DC fast charging mode [64].

From the perspective of automobile companies, they considered that direct charging mode has more benefits. Plug-in EVs have been exploited by the companies, such as Cherry, JAC, FAW, and SAIC. All these companies have realized production or owned production plans for plug-in EVs and many models are in commissioning phase. As a result, it will increase the enormous cost if the battery-replacement mode is in the ascendant, since these enterprises need to develop new products.

In June 2012, the State Council formally issued "Energy Saving and New Energy Automobile Industry Development Planning (2012-2020)", in which government put forward "promoting charging infrastructure construction", while simply mentioned "exploring a variety of business models for NEVs, battery lease, and the service of charging and battery replacement" [65]. From this policy, it could be inferred that the government is inclined to the charging mode, which further means enterprises should raise the funds by themselves in the promotion of battery-replacement mode. However, is it right to abandon the battery-replacement mode? Considering the effects of two modes for grid and the existing successful cases in pilot cities, it seems more sensible to judge ways according to vehicle models. For instance, it is ideally suitable to develop the way of changing battery for the public cars (bus and taxi) because of the limitation of charging time, the predictable mileage, and unified management by the 
enterprises. On the other hand, it is also appropriate to develop the way of direct charging for private vehicles and official vehicles owing to their various models, not unified standards for batteries and mode of short running during the day and stopping at night.

\subsection{Policy Suggestions}

\subsubsection{Promoting the Standardized Development of Low-Speed EVs}

As mentioned above, although there are many problems for the low-speed EVs, this type of vehicle does own a large market demand. If properly guided, low-speed EVs will promote the development of the whole EV market. It will not only change people's consumption concept, but, also, be beneficial for the cultivation of the EV parts industry. From the perspective of sustainable development, the promotion of EVs should start from the low-level and gradually upgrade to intermediate-level and finally across to the high-end. Therefore, the government should cooperate with enterprises to promote the standardized development of low-speed EVs in following ways. Firstly, formulate relevant technical parameters and quality standards to improve the safety of low-speed EVs. Secondly, incorporate it into the "directory" to assure its legalization, protect the interests of consumers and manufacturers, as well as enhance the consumers' consumption willingness. Thirdly, encourage enterprises to improve low-speed EVs' technology to make the speed fulfill the requirements of road motor vehicles and ensure its safety meet national mandatory safety requirements. Eventually, regulate and expand low-speed EVs driving area by setting special licenses or other manners.

\subsubsection{Adjusting Financial Subsidies}

Local protectionism phenomenon is largely arising from the inapposite ways of state's subsidies for NEVs. Since 2009, when China begun to implement the NEV subsidy policies for pilot cities, most local governments strongly support local automobile companies in order to increase their local taxation and GDP performance. In doing so, some local governments set rigorous threshold to companies in other regions. For example, the outside company is required to re-establish factory in the prefecture of local government, which could contribute to local economy performance. However, because repeated investment results in reduced R\&D fund, a lot of adverse effects have appeared, such as excellent products are limited, the EV market becomes deformed, some car companies' investments are aggravating and the advancement of NEV technology is contained. Therefore, the government should change the subsidy ways. On one hand, it is more sensible to convert urban-oriented subsidies into company-driven subsidies. China's central government could elect automobile companies who possess advanced technology, strong foundation, high market reputation, and good product reflection as target subsidies, then motivate them truly committed to new technology research, good products development, and new markets exploration, thus, a robust market environment could be established. On the other hand, facing the fact that public EVs are promoted faster than the privates at this stage, the central government could require local governments to purchase a certain percentage of preponderant brands in other regions when purchasing public EVs. If there were no such limitations, the local protectionism would be difficult to break. As stated earlier when local government purchases the NEVs, the procurement of local brands actually makes the money in internal transfer and will increase the local GDP. In addition, some 
governments will couple the subsidies on the basis of state subsidies for which these governments prefer to give subsidies to local auto manufactures. Through setting limitations, some cities would be forced to break local protectionism, introduce competition mechanism and create breakthroughs in technology, quality and cost. Consequently, a fair EV market could be established. Inspiringly, MF, MIIT, and NDRC have just issued "Notice on the continuation of the promotion and application of new energy vehicles". It specified that local government should ensure outside brand products account for at least $30 \%$ of purchases in order to break local monopolies. In addition, government agencies as well as public institutions are required to purchase NEVs. Under this policy guidance, local protectionism phenomenon will be gradually eased.

Meanwhile, vehicle itself is still the main target of existing subsidy policy, while fast charging infrastructure, the prerequisite for the promotion of EVs, does not enjoy corresponding subsidies. Current market reality is that vehicle itself and charging infrastructure are two mutual restraint individuals. Car companies limit the NEVs production since the charging infrastructure is insufficient, which in turn negatively impacts the construction of charging facilities. Therefore, a national progressive subsidy combination mechanism should cover vehicle purchase, related parts, key technologies and supporting infrastructure.

\subsubsection{Sustainable Financing Mechanism of Subsidies}

In the future, the spending used to subsidize EVs and related infrastructure will increase with the development of EVs. Due to the large fixed cost of charging infrastructure, it is difficult to meet the huge cost requirements for the State Grid, Sinopec, and other enterprises alone. Thus, the sustainable development of EVs still needs innovative subsidy financing mechanisms. Government should introduce private capital into the construction of charging facilities since there is abundant private capital while lacking investment channels in China. In addition, because NEVs are environmentally friendly, some measures are benefit for NEVs' development from the international experiences. For example, carbon emissions trade and carbon tax or environment tax are effective measures to mitigate climate change approved by the practices of many countries. China's government should introduce these measures as quickly as possible. These measures are efficient to offset part of the charging facility expenses and provide a sustainable subsidy financing mechanisms for EVs. Moreover, national policy banks, commercial banks, various types of financial intermediaries, and the regional credit guarantee centers could together give priority to provide loans and guarantees to NEV companies. Through moderately relaxing lending conditions, lowering loan interest rates, increasing the intensity of discount loans, and actively expanding financing channels, a good financing environment for private enterprises engaged in the NEV field could be provided.

\subsubsection{Compared with Subsidies, Obvious ICEV Limitation Policies May Be More Effective}

Since 2009, when China started to vigorously promote NEVs, the government has formulated numbers of subsidy policies for vehicles' R\&D and consumer purchase. However, the promotion effect is still far behind the target. In the field of public vehicles, local governments and automakers have formulated the plans for EVs in buses and other special areas in response to national policies, yet private EVs still struggled to expand market situation. 
At this stage, the promotion of NEVs is mainly reflected in tax subsidy ways, what causes the doubt that whether subsidies alone could greatly expand EV market. Recall China's development experience of electric bicycles, there were tremendous attempts to commercialize electric bikes and scooters, but all failed before the latter 1990s. Then, the electric bike market in China underwent a great deal of success until the late 1990s, facilitated by favorable local regulatory practices in the form of motorcycle bans and loose enforcement of electric bike standards. These local motorcycle bans became the ultimate driver for the electric bike boom in China [66,67]. By contrast, the experience of Taiwan was just the opposite. The government has developed a quantity of subsidies, covering car prices, charging facilities, R\&D funds, and the consumer price, among which there is no limitation for the gasoline-fueled scooters. Consequently, Taiwan has not established a stable electric bike market so far. Therefore, subsidies alone may not be a sufficient development strategy [68]. A new technology always requires a long period of time for promotion. Moreover, the failure of consumer's first experience will always ruin a promising new technology. Therefore, only one way can bear fruits, that is a promotion with no alternatives. Only in this way should consumers try over and over again, providing buffer time for technical development and gradually accept it.

It is obviously impossible to prohibit traditional fuel vehicles on the road in current situation with such a large number of customers. Thus, will China's EVs not be able to form a stable market? The answer, we insisted, is no. Though the government would not take this one-time restriction, incremental restrictions still could be applied. In terms of vehicle purchase fees, even if the EVs could reach a comparable price with price subsidy policy, their competitiveness with conventional fuel vehicles is still not enough. Put another way, other subsequent measures could be employed to reduce the competitiveness of traditional vehicles. For instance, charging parking fees and tolls only for traditional fuel vehicles, provide enough NEVs-only parks, waive the license fee for EVs, a longer warranty period, and preferential charging tariff EVs could enjoy. In addition, China could learn from London's experience of introducing stringent congestion fees for traditional fuel vehicles, and, then, alternative cars exempted from the charges are booming [69]. Through these efforts, a single subsidy policy will be transformed into a parallel combination of subsidy and limitation policies and it will guide the consumers' willingness to buy EVs. In this way, EV technology updates buffering time will be extended, traditional fuel vehicles will gradually fade out and a stable EV market will be gradually established.

\section{Conclusions}

In 2009, China officially launched a wide range of promotion for EVs, set ambitious development goals, and introduced a variety of supportive policies covering pilot programs, infrastructure planning, tax subsidies, price subsidies, and R\&D investment. However, the actual scale of EVs had lagged far behind the target by 2012. Under the premise that China's power structure is dominated by coal, disorder charging of EVs cannot really achieve the significance of energy conservation. Moreover, inherent technical problems of EV have not been well solved, either. Particularly, some market embarrassments appeared guided by the subsidy policies. For example, low-speed electric vehicles with good market reaction are not promoted by the government, local protectionism is becoming increasingly serious, and private EVs are still delayed in the expanding market. 
China's EV development faces a new round of challenges. We believe that it is more sensible to give priority to developing public EVs and the style of $\mathrm{HEV}$, treat them as transitions to explore the EV market. Through this path, consumers could gradually accept the EV concept, infrastructure scale could be gradually expanded, and an orderly charging model will be well established. In addition, various charging modes, including battery replacement, are needed to meet the diverse demands of different users.

Owing to no corresponding support policies for popular low-speed EVs, it is suggested that government could absorb them into the development directory, formulating appropriate technical specifications and standards to prompt them to lead the overall development as market pioneers. At the same time, the government could encourage various types of financial intermediaries broadly participate in new energy projects, and make financing funds better covering vehicles, supporting charging facilities and related technologies, and other fields. Moreover, the method what seems easier to build a more comprehensive and balanced EV market is that to regard the enterprises as the objects of subsidies rather than cities. In addition, it is desirable to formulate limitation polices for traditional fuel vehicles to improve the competitiveness of EVs.

\section{Acknowledgments}

The authors would like to thank the anonymous referees and the editor of this journal. The authors gratefully acknowledge the financial support by the National Natural Science Foundation of China (Grant no. 71173075 and 71373077), Beijing Natural Science Foundation of China (Grant no.9142016), Beijing Planning Project of Philosophy and Social Science (Grant no. 13JGB054), Ministry of Education Doctoral Foundation of China (Grant no.20110036120013), Program for New Century Excellent Talents in University (NCET-12-0850), and the Fundamental Research Funds of the Central Universities of China.

\section{Author Contributions}

In this paper, Xingping Zhang developed the research ideas and implemented research programs; Rao Rao committed to figure out how to establish a stable EV market in China and completed the writing work of Section 3; Jian Xie collected and collated the related policies about EV in China, including pilot policy, infrastructure promotion policy, price subsidy, tax policy, and R\&D policy; Yanni Liang carried out the research about obstacles for EV development in China and completed the writing work of corresponding parts.

\section{Conflicts of Interest}

The authors declare no conflict of interest.

\section{References}

1. Zhang, M.; Li, H.N.; Zhou, M.; Mu, H.L. Decomposition analysis of energy consumption in Chinese transport sector. Appl. Energ. 2011, 88, 2279-2285 
2. Zhang, M.; Mu, H.L.; Li, G.; Ning, Y.D. Forecasting the transport energy demand based on PLSR method in China. Energy 2009, 34, 1396-1400.

3. National Bureau of Statistics of China. China Energy Statistical Yearbook 2010; China Statistics Press: Beijing, China, 2011, Appendix IV.

4. Oliver, H.H.; Gallagher, K.S.; Tian, D.L.; Zhang, J.H. China's fuel economy standards for passenger vehicles: Rationale, policy process, and impacts. Energ. Policy 2009, 37, 4720-4729.

5. Oil Balance Sheet. National Bureau of Statistics of China. Available online: http://data.stats.gov.cn/workspace/index;jsessionid=7C83B1B399442E8AADF5BEC7033E8F99? $\mathrm{m}=$ hgnd (accessed on 20 December 2013). (In Chinese)

6. Wang, Y.F.; Li, K.P.; Xu, X.M.; Zhang, Y.R. Transport energy consumption and saving in China. Renew. Sust. Energ. Rev. 2014, 29, 641-655.

7. The Number of Cities. National Bureau of Statistics of China. Available online: http://data.stats.gov.cn/workspace/index;jsessionid=7C83B1B399442E8AADF5BEC7033E8F99? $\mathrm{m}=$ hgnd (accessed on 20 December 2013). (In Chinese)

8. Population Profile. National Bureau of Statistics of China. Available online: http://data.stats.gov.cn/workspace/index;jsessionid=7C83B1B399442E8AADF5BEC7033E8F99? $\mathrm{m}=$ hgnd (accessed on 20 December 2013). (In Chinese)

9. National Bureau of Statistics of People's Republic of China. China Statistical Yearbook 2011; China Statistics Press: Beijing, China, 2012.

10. Cheng S.Y.; Zhou, Y.; Li, J.B.; Lang, J.L.; Wang, H.Y. A new statistical modeling and optimization framework for establishing high-resolution $\mathrm{PM}_{10}$ emission inventory-I. Stepwise regression model development and application. Atmos. Environ. 2012, 60, 613-622.

11. Reasons for the formation of fog and haze in Beijing. Weather Network. Available online: http://beijing.tianqi.com/news/19155.html (accessed on 9 October 2013). (In Chinese)

12. Huang, J.X. The Development Path of EV Industry and Policy Research. Master Thesis, Beijing Jiaotong University, Beijing, 4 July 2010.

13. Wang, C.; Zhu, C. Energy-saving and New Energy Automobile Production Monthly Production Report. Automobile Industry Development Institute of China 2013, 10, 3-11.

14. An, H.Y. Policy Interpretation and Suggestion on New Energy Automotive Industry in China. Sci. Technol. Manage. Res 2012, 10, 29-32.

15. Luo, X.M. An Analysis on EV Industrial Development Based on Game Theory. Master Thesis, Wuhan University of Technology, Wuhan, China, April 2006.

16. Jia, J.G. EV Support Policies in Some Countries. State Grid 2007, 4, 43-45.

17. Wu, Y.Z; Wang, K.; Wei, Z.L.; Xin, M. Matching policies of Chinese electric vehicles industry development. Power DSM 2008, 10, 71-74

18. Notice on launching pilot demonstration projects of energy-saving and new energy vehicle. The Central People's Government of the People's Republic of China. Available online: http://www.gov.cn/zwgk/2009-02/05/content_1222338.htm (accessed on 13 December 2013). (In Chinese)

19. Notice on expanding the demonstration of energy-saving and new energy vehicle in public services. Ministry of Industry and Information Technology of the People's Republic of China. Available online: 
http://www.miit.gov.cn/n11293472/n11293832/n11293907/n11368223/13247379.html (accessed on 13 December 2013). (In Chinese)

20. Notice on launching pilot projects of subsidy policy for purchase of private new energy vehicle. Ministry of Finance of the People's Republic of China. Available online: http://jjs.mof.gov.cn/ zhengwuxinxi/zhengcefagui/201005/t20100531_320528.html (accessed on 13 December 2013). (In Chinese)

21. Guidance on promoting the application of new energy vehicles in Jiangsu province. People's Government of Jiangsu Province. Available online: http://www.jiangsu.gov.cn/jsyw/201203/ t20120306_719375.html (accessed on 13 December 2013). (In Chinese)

22. Catalogue for the guidance of industrial structure adjustment. The Development and Reform Admininstration of the People's Republic of China. Available online: http://www.gdbz.gov.cn/ public/LawsItem.aspx?id=2252 (accessed on 13 December 2013). (In Chinese)

23. Notice on further improvement of pilot demonstration projects of energy-saving and new energy vehicle. Ministry of Science and Technology of the People's Republic of China. Available online: http://www.most.gov.cn/tztg/201111/t20111110_90811.htm (accessed on 13 December 2013). (In Chinese)

24. No. 21 national standard announcement of the People's Republic of China in 2011. Standardization Admininstration of the People's Republic of China. Available online: http://www.sac.gov.cn/ gjbzgg/201121/ (accessed on 13 December 2013). (In Chinese)

25. The Twelfth-Five Year special planning of the technology development of electric vehicles. The Central People's Government of the People's Republic of China. Available online: http://www.gov.cn/ zwgk/2012-04/20/content_2118595.htm (accessed on 13 December 2013). (In Chinese)

26. Sun, X.H.; Liu, K.; Zuo, Z.H. Strategic study on framework of electric vehicle subsidy policies. Sci. Technol. Manage. Res. 2011, 13, 99-103.

27. Financial subsidy interim measures for energy-saving and new energy vehicles' demonstration and extension in pilot cities. Ministry of Finance of the People's Republic of China. Available online: http://www.mof.gov.cn/zhengwuxinxi/caizhengwengao/2009niancaizhengbuwengao/caizhengwen gao2009dierqi/200904/t20090413_132178.html (accessed on 14 December 2013). (In Chinese)

28. Financial subsidy interim measures for private purchase of new energy vehicle in pilot cities. Ministry of Finance of the People's Republic of China. Available online: http://jx.mof.gov.cn/ lanmudaohang/zhengcefagui/201007/t20100729_330673.html (accessed on 14 December 2013). (In Chinese)

29. Management approach on the private purchase of BEVs in Beijing (trial implementation). ChinaIRN. Available online: http://www.chinairn.com/news/20121025/147930.html (accessed on 14 December 2013). (In Chinese)

30. Yu, J.T.; Zhang, Y.W.; Gao, S.J. U.S. Electric vehicle development status, the policy system and the next possible actions. Res Report 2010, 5, 22-24.

31. Yang, F.; Zhang, Y.B.; Ge, X.B. Electric Vehicle Development Tendency and Characteristics in China, USA and Japan. Energ. Technol. Econ.2011, 23, 40-44.

32. Fu, X.; Wang, Y.N.; Hu, B.X. Foreign policy research to promote the electric car industry. Shanghai Automot. 2007, 2, 7-10. 
33. Notice on adjusting and improving the consumption tax policy. Ministry of Finance of the People's Republic of China. Available online: http://www.mof.gov.cn/zhengwuxinxi/bulinggonggao/ tongzhitonggao/200805/t20080519_23541.html (accessed on 14 December 2013). (In Chinese)

34. Vehicle and vessel tax implementation methods in Henan province. The People's Government of Henan Province. Available online: http://www.henan.gov.cn/zwgk/system/2011/12/28/010283949. shtml (accessed on 14 December 2013). (In Chinese)

35. Bulletin of directory of BEVs and ICEVs models which are not free of travel taxes. State Administration of Taxation. Available online: http:/www.chinatax.gov.cn/n8136506/n8136593/ n8137537/n8138502/11790011.html (accessed on 14 December 2013). (In Chinese)

36. Notification from combination of Ministry of Finance, State Administration of Taxation and MIIT. The Central People's Government of the People's Republic of China. Available online: http://www.gov.cn/zwgk/2012-03/07/content_2085756.htm (accessed on 14 December 2013). (In Chinese)

37. Development and application of Key technologies of clean energy vehicles. People.com. Available online: http://www.people.com.cn/GB/paper1668/7739/737737.html (accessed on 15 December 2013). (In Chinese)

38. Energy saving and new energy vehicles. Ministry of Science and Technology of the People's Republic of China. Available online: http://www.most.gov.cn/tztg/200610/t20061025_36542.htm (accessed on 15 December 2013). (In Chinese)

39. Key technology and system integration of EV in modern transportation technology area. Ministry of Science and Technology of the People's Republic of China. Available online: http://www.most. gov.cn/tztg/201010/P020101028623871204363.pdf (accessed on 15 December 2013). (In Chinese)

40. Electric Power Research Institute (EPRI). Environmental Assessment of Plug-In Hybrid Electric Vehicles_Volume 1: Nationwide Greenhouse Gas Emissions; EPRI: California, USA, 2007.

41. Grahn, M.; Klampfl, E.; Whalen, M.; Wallington, T.J. Sustainable mobility: Using a global Energy model to inform vehicle technology choices in a decarbonized economy. Sustainability 2013, 5, $1845-1862$.

42. Wu, Y.; Yang, Z.D.; Lin, B.H.; Liu, H.; Wang, R.J.; Zhou, B.Y.; Hao, J.M. Energy consumption and $\mathrm{CO}_{2}$ emission impacts of vehicle electrification in three developed regions of China. Energ. Policy 2012, 48, 537-550.

43. National thermal power installed capacity returns to account for less than $70 \%$ in 2013 . Website of coal study. Available online: http://www.coalstudy.com/news/dlhgzx/d1/2013-12-09/1364.html (accessed on 9 December 2013). (In Chinese)

44. Mousazadeh, H.; Keyhani, A.; Javadi, A.; Mobli, H.; Abrinia, K.; Sharifi, A. Evaluation of alternative battery technologies for a solar assist plug-in hybrid electric tractor. Transport Res. D-Tr. E. 2010, 15, 507-512.

45. Amjad, S.; Rudramoorthy, R.; Neelakrishnan, S.; Varman, K.S.R.; Arjunan, T.V. Impact of real world driving pattern and all-electric range on battery sizing and cost of plug-in hybrid electric two-wheeler. J. Power Sources 2011, 196, 3371-3377.

46. Shiau, C.S.N.; Samaras, C.; Hauffe, R.; Michalek, J.J. Impact of battery weight and charging patterns on the economic and environmental benefits of plug-in hybrid vehicles. Energ. Policy 2009, $37,2653-2663$. 
47. Hidrue, M.K.; Parsons, G.R.; Kempton, W.; Gardner, M.P. Willingness to pay for electric vehicles and their attributes. Resour. Energ. Econ. 2011, 33, 686-705.

48. EVDays.com. Available online: http://www.evdays.com/eccar/index.html (accessed on 14 January 2014). (In Chinese)

49. People's Life. National Bureau of Statistics of China. Available online: http:/data.stats.gov.cn/ workspace/index?m=hgnd (accessed on 20 December2013). (In Chinese)

50. Zhang, L.; Fang, H.F. China's low-speed electric vehicle industry status and development ideas. Aut. Ind. Res. 2013, 1, 24-27.

51. Zhang, L.; Fang, H.F. Development Status of Small Low-speed EV in China. New Energ. Vehicles 2010, $5,38-41$.

52. Local protection: Barrier to electric vehicles. Phoenix Automotive. Available online: http:// auto.youth.cn/news/20130701/story_433383.html (accessed on 1 July 2013). (In Chinese)

53. Huo, H.; Zhang, Q.A.; Wang, M.Q.; Streets, D.G.; He, K.B. Environmental implication of electric vehicles in China. Environ. Sci. Technol. 2010, 44, 4856-4861

54. Ou, X.M.; Zhang, X.L.; Chang, S.Y. Alternative fuel buses currently in use in China: Life-Cycle fossil energy use, GHG emissions and policy recommendations. Energ. Policy 2010, 38, 406-418.

55. Yao, M.F.; Liu, H.F.; Feng, X. The development of low-carbon vehicles in China. Energ. Policy 2011, 39, 5457-5464.

56. Hu, X.J.; Chang, S.Y.; Li, J.J.; Qin, Y.N. Energy for sustainable road transport in China: Challenges, initiatives and policy implications. Energy 2010, 35, 4289-4301.

57. Siang, F.T.; Chee, W.T. A review of energy sources and energy management system in electric vehicles. Renew. Sust. Energ. Rev. 2013, 20, 82-102.

58. Anurag, K.S.; Bharath, A.; Sukumar, K. The Challenges and Policy Options for Integrating Plug-in Hybrid Electric Vehicle into the Electric Grid. The Electricity J. 2010, 23, 83-91.

59. Higgins, A.; Paevere, P.; Gardner, J.; Quezada, G. Combining choice modeling and multi-criteria analysis for technology diffusion: An application to the uptake of electric vehicles. Technol. Forecast. Soc. Change 2012, 79, 1399-1412.

60. Hackbarth, A.; Madlener, R. Consumer preferences for alternative fuel vehicles: A discrete choice analysis. Transport Res. D-Tr. E. 2013, 25, 5-17.

61. Chinese consumers' willingness to buy electric vehicles. Ernst \& Young survey. Available online: http://www.dajudeng.com/d20120810043138ed5b9f3f90f76c61b16.html (accessed on 2 March 2014). (In Chinese)

62. Sina Finance and Economics. Available online: http://finance.sina.com.cn (accessed on 4 June 2011). (In Chinese)

63. Anonymous. "Direct Charge" or "Battery Replacement"-Running under the Interests. World Power Supply 2012, 8, 4-6. (In Chinese)

64. Li, H.L.; Bai, X.M. Impacts of electric vehicles charging on distribution grid. Automt. Electr. Power Syst. 2011, 35, 38-43.

65. Hu, Y.X. EV Energy Supply: Direct Charging or Battery Replacement. Electr. Bicycle 2011, 7, 17-18.

66. Weinert, J.; Ma, C.; Cherry, C. The transition to electric bikes in China: History and key reasons for rapid growth. Transportation 2007, 34, 301-318. 
67. Weinert, J.; Ogden, J.; Sperling, D.; Burke, A. The future of electric two-wheelers and electric vehicles in China. Energ. Policy 2009, 36, 2544-2555.

68. Yang, C.J. Launching strategy for electric vehicles: Lessons from China and Taiwan. Technol. Forecast. Soc. Change 2010, 77, 831-834.

69. Grünweg, T. London's electric avenues: New playground for alternative cars. Spiegel Online, August 14 2008. Available online: http://www.spiegel.de/international/europe/london-s-electricavenues-new-playground-for-alternative-cars-a-572118.html (accessed on 28 December 2013).

\section{Appendix}

Appendix. Prices of EVs or HEVs sold in China.

\begin{tabular}{|c|c|c|c|c|c|c|c|c|}
\hline Model & Price (Yuan) & Type & Model & Price (Yuan) & Type & Model & Price (Yuan) & Type \\
\hline Audi Q5 & 608,000 & HEV & $\begin{array}{c}\text { Volkswagen } \\
\text { Touareg } \\
\end{array}$ & $1,380,000$ & HEV & $\begin{array}{c}\text { Mazda CX-5 } \\
\text { SKYAC }\end{array}$ & 252,800 & HEV \\
\hline Audi A6 & 445,000 & HEV & $\begin{array}{c}\text { Volkswagen } \\
\text { Magotan } \\
\text { BlueMotion }\end{array}$ & 219,800 & HEV & Mazda Demio & 287,700 & $\mathrm{EV}$ \\
\hline Audi A8L & $1,090,000$ & HEV & $\begin{array}{c}\text { Golf } \\
\text { BlueMotion }\end{array}$ & 235,800 & HEV & $\begin{array}{c}\text { Opel } \\
\text { Amepera }\end{array}$ & 383,000 & PHEV \\
\hline BYD e6 & 369,800 & BEV & $\begin{array}{c}\text { Volkswagen } \\
\text { PASSaT } \\
\text { BlueMotion }\end{array}$ & 212,800 & HEV & Acura ILX & 328,000 & HEV \\
\hline BYD F3DM & 169,800 & HEV & $\begin{array}{c}\text { Volkswagen } \\
\text { Sagitar } \\
\text { BlueMotion }\end{array}$ & 169,800 & HEV & Chery QQ3 & 52,800 & $\mathrm{EV}$ \\
\hline BYD QING & 189,800 & PHEV & Toyota Prius & 300,000 & PHEV & $\begin{array}{c}\text { Chery Riich } \\
\text { M1 }\end{array}$ & 149,800 & $\mathrm{EV}$ \\
\hline Honda FIT & 179,800 & HEV & $\begin{array}{c}\text { Toyota Prius } \\
3\end{array}$ & 229,800 & HEV & Kia K5 & 289,800 & HEV \\
\hline Honda FIT & 323,800 & $\mathrm{EV}$ & $\begin{array}{c}\text { Toyota } \\
\text { Kamimizu }\end{array}$ & 259,800 & HEV & Nissan LEAF & 240,000 & $\mathrm{EV}$ \\
\hline Honda Insight & 209,800 & HEV & Toyota-EVIII & 310,000 & $\mathrm{EV}$ & Roewe E1 & 80,000 & $\mathrm{EV}$ \\
\hline Honda CR-Z & 288,800 & HEV & $\begin{array}{c}\text { Toyota } \\
\text { Highlander }\end{array}$ & 287,700 & HEV & Roewe 750 & 226,800 & HEV \\
\hline $\begin{array}{c}\text { BMW } \\
\text { ActiveX6 }\end{array}$ & $2,168,000$ & HEV & $\begin{array}{l}\text { Toyata } \\
\text { Avalon }\end{array}$ & 222,000 & HEV & Roewe 750D & 150,000 & HEV \\
\hline $\begin{array}{c}\text { BMW Active } \\
\text { Hybrid } 7\end{array}$ & $1,488,000$ & HEV & Ford Mondeo & 174,000 & HEV & Roewe E50 & 234,900 & $\mathrm{EV}$ \\
\hline $\begin{array}{c}\text { BMW Active } \\
\text { Hybrid } 3\end{array}$ & 661,600 & HEV & Ford C-Max & 162,000 & HEV & Mitsubishi-Mi & 330,000 & $\mathrm{EV}$ \\
\hline $\begin{array}{c}\text { BMW Active } \\
\text { Hybrid } 5\end{array}$ & 878,000 & HEV & Ford Fox & 248,000 & $\mathrm{EV}$ & $\begin{array}{c}\text { Mitsubishi } \\
\text { Outlander }\end{array}$ & 188,900 & HEV \\
\hline $\begin{array}{c}\text { Buick Regal } \\
\text { eAssist }\end{array}$ & 249,900 & HEV & Fisker Karma & $1,680,000$ & REEV & $\begin{array}{c}\text { Tesla Model } \\
\text { X }\end{array}$ & 471,300 & $\mathrm{EV}$ \\
\hline
\end{tabular}


Appendix. Cont.

\begin{tabular}{|c|c|c|c|c|c|c|c|c|}
\hline Model & Price (Yuan) & Type & Model & Price (Yuan) & Type & Model & Price (Yuan) & Type \\
\hline $\begin{array}{l}\text { Mercedes-Benz } \\
\quad \text { S 400L }\end{array}$ & $1,458,000$ & HEV & Ferrari F150 & $9,960,000$ & HEV & Tesla Model S & 734,000 & $\mathrm{EV}$ \\
\hline $\begin{array}{l}\text { Mercedes-Benz } \\
\text { Smart ForTwo }\end{array}$ & 100,000 & $\mathrm{EV}$ & Fiat500 & 630,000 & $\mathrm{EV}$ & $\begin{array}{c}\text { Tesla } \\
\text { Roadster }\end{array}$ & 800,000 & $\mathrm{EV}$ \\
\hline $\begin{array}{l}\text { Mercedes-Benz } \\
\text { E300 BlueTEC }\end{array}$ & 392,000 & HEV & Haima & 109,800 & $\mathrm{EV}$ & Volvo V60 & 414,000 & PHEV \\
\hline $\begin{array}{c}\text { Mercedes-Benz } \\
\text { E400 }\end{array}$ & 355,000 & HEV & Hafei Saibao & 150,000 & $\mathrm{EV}$ & Volvo C30 & 462,900 & $\mathrm{EV}$ \\
\hline $\begin{array}{c}\text { Mercedes-Benz } \\
\text { SLS E-cell }\end{array}$ & $3,375,200$ & $\mathrm{EV}$ & Hawtai B11 & 150,000 & EV & $\begin{array}{l}\text { Citroen } \\
\text { C-Zero }\end{array}$ & 45,000 & EV \\
\hline BAW C30 & 300,000 & EV & Geely EK2 & 80,000 & EV & Citroen DS3 & 249,800 & EV \\
\hline Foton MIDI & 270,000 & EV & Geely EC7 & 79,800 & $\mathrm{HEV}$ & Citroen DS5 & 259,900 & HEV \\
\hline BAW E150 & 220,000 & EV & JAC Aiyiwei & 150,000 & EV & $\begin{array}{c}\text { Chevolet Sail } \\
\text { Spring }\end{array}$ & 258,000 & EV \\
\hline BAW Saab & 188,000 & $\mathrm{EV}$ & JAC Tojoy & 98,800 & $\mathrm{EV}$ & $\begin{array}{c}\text { Chevolet } \\
\text { Spaak }\end{array}$ & 155,400 & EV \\
\hline $\begin{array}{l}\text { Porsche } \\
\text { Cayenne }\end{array}$ & $1,396,000$ & $\mathrm{HEV}$ & $\begin{array}{l}\text { Cadillac } \\
\text { Escalade }\end{array}$ & $1,588,000$ & $\mathrm{HEV}$ & Chevolet Volt & 498,000 & REEV \\
\hline $\begin{array}{c}\text { Porsche } \\
\text { Panamera }\end{array}$ & $1,751,000$ & HEV & Lifan 620 & 150,000 & $\mathrm{EV}$ & $\begin{array}{l}\text { Hyundai } \\
\text { Sonata YF }\end{array}$ & 168,500 & HEV \\
\hline $\begin{array}{c}\text { Porsche } 918 \\
\text { Spyder }\end{array}$ & $5,285,000$ & HEV & $\begin{array}{c}\text { Lexus } \\
\text { CT200h }\end{array}$ & 279,000 & $\mathrm{HEV}$ & $\begin{array}{c}\text { FAW Besturn } \\
\text { B70 }\end{array}$ & 200,000 & HEV \\
\hline $\begin{array}{c}\text { Peugeot } 3008 \\
\text { Hybrid4 }\end{array}$ & 350,000 & HEV & $\begin{array}{c}\text { Lexus } \\
\text { GS450h }\end{array}$ & 975,000 & HEV & $\begin{array}{c}\text { FAW Besturn } \\
\text { B50 }\end{array}$ & 150,000 & HEV \\
\hline $\begin{array}{c}\text { Peugeot508 } \\
\text { RXH }\end{array}$ & 296,400 & HEV & $\begin{array}{c}\text { Lexus } \\
\text { LS600hL }\end{array}$ & $2,388,000$ & $\mathrm{HEV}$ & $\begin{array}{c}\text { FAW Besturn } \\
\text { B50 }\end{array}$ & 200,000 & $\mathrm{EV}$ \\
\hline DENZA & 350,000 & EV & $\begin{array}{c}\text { Lexus } \\
\text { RX450h }\end{array}$ & 945,000 & HEV & $\begin{array}{c}\text { Infinity } \\
\text { EMERG-E }\end{array}$ & 950,000 & HEV \\
\hline Changan Benni & 100,000 & EV & $\begin{array}{l}\text { Lexus } \\
\text { ES300h }\end{array}$ & 399,000 & $\mathrm{HEV}$ & $\begin{array}{l}\text { Infinity } \\
\text { M35hL }\end{array}$ & 718,000 & HEV \\
\hline Changan E30 & 300,000 & EV & Renault Zoe & 137,000 & $\mathrm{EV}$ & Zotye M300 & 270,000 & EV \\
\hline $\begin{array}{c}\text { Changan Benni } \\
\text { mini }\end{array}$ & 150,000 & EV & $\begin{array}{c}\text { Renault } \\
\text { Kangoo Z.E. }\end{array}$ & 73,000 & $\mathrm{EV}$ & Zotye 5008 & 220,000 & EV \\
\hline $\begin{array}{c}\text { Volkswagen } \\
\text { E-Up }\end{array}$ & 140,000 & $\mathrm{EV}$ & Suzuki Swift & 182,000 & PHEV & & & \\
\hline
\end{tabular}

(C) 2014 by the authors; licensee MDPI, Basel, Switzerland. This article is an open access article distributed under the terms and conditions of the Creative Commons Attribution license (http://creativecommons.org/licenses/by/3.0/). 